\title{
ASPEK BIOLOGI DAN PEMANFAATAN IKAN TENGGIRI PAPUA (Scomberomorus multiradiatus Munro, 1964) DENGAN ALAT TANGKAP JARING INSANG DI PERAIRAN MERAUKE DAN SEKITARNYA
}

\author{
BIOLOGICAL ASPECTS AND EXPLOITATION PAPUAN SEERFISH \\ (Scomberomorus multiradiatus Munro, 1964) WITH GILLNET IN MERAUKE \\ WATERS AND ADJACENTS
}

\author{
Andina Ramadhani Putri Pane*, Karsono Wagiyo dan Ali Suman \\ Balai Riset Perikanan Laut, Cibinong, Bogor, 16912, Indonesia \\ *E-mail. andina1984@gmail.com
}

\begin{abstract}
Papuan mackerel (Scomberomorus multiradiatus) is a Papua endemic fish caught only in Merauke waters and adjacents. The exploitation of this fish by local people with the level of production has increased from year to year. In the management of Papuan mackerel fish populations, scientific studies are needed about biological aspects and their use by drifting gillnets. The study was conducted for 2 (two) years, March - December 2017 and April - December 2018 with survey methods assisted by enumerators monthly. Data on the composition of the catch of the gillnet drift dominantly demersal fish because it is operated in shallow waters that sweep to the bottom. Papuan mackerel is only about $6-10 \%$ of the total catch with a dominant size structure at $40 \mathrm{~cm}$ FL (fork length) and allometric positive growth pattern. The sex ratio of the fish is unbalanced with the male dominant compared to the female. The size of the first fish caught is getting smaller in size, namely 32.08 (2017) to 30.50 (2018) which can be an indication that the fish size is getting smaller. The growth rate $(K)$ is around 0.64 which shows that the growth rate is relatively slow with the rate of death due to capture $(F)$ higher than natural death $(M)$. The exploitation of this fish has reached $E=0.70$ or $140 \%$, so a $40 \%$ reduction must be made from the current effort and by developing local wisdom so that the endemic fish population is maintained.
\end{abstract}

Keywords: biological aspects, exploitation leve, FMA 718l, Merauke, Papuan seerfish

\begin{abstract}
ABSTRAK
Ikan tenggiri Papua (Scomberomorus multiradiatus) adalah ikan endemik Papua yang tertangkap hanya di sekitar perairan Merauke. Pemanfaatan ikan ini oleh masyarakat lokal dengan tingkat produksi mengalami peningkatan dari tahun ke tahun. Dalam pengelolaan populasi ikan tenggiri Papua diperlukan kajian ilmiah tentang aspek biologi dan pemanfaatannya dengan menggunakan jaring insang hanyut. Penelitian dilakukan selama 2 (dua) tahun yaitu Maret - Desember 2017 dan April Desember 2018 dengan metode survei yang dibantu oleh enumerator secara bulanan. Data komposisi hasil tangkapan jaring insang hanyut dominan ikan demersal karena dioperasikan di perairan dangkal yang menyapu hingga ke dasar. Ikan tenggiri Papua hanya sekitar 6-10\% dari total tangkapan dengan struktur ukuran dominan pada $40 \mathrm{cmFL}$ (fork length) dan pola pertumbuhan allometrik positif. Nisbah kelamin ikan tidak seimbang dengan dominan jantan dibandingkan betina. Ukuran ikan yang pertama kali tertangkap semakin kecil ukurannya yaitu 32.08 (2017) menjadi 30.50 (2018) yang dapat menjadi indikasi bahwa ukuran ikan semakin kecil. Laju pertumbuhan $(\mathrm{K})$ sekitar 0.64 yang menunjukkan laju pertumbuhan tergolong lambat dengan laju kematian akibat penangkapan (F) lebih tinggi dibandingkan kematian alamiah (M). Pemanfaatan ikan ini sudah mencapai $E=0,70$ atau $140 \%$ sehingga harus dilakukan pengurangan $40 \%$ dari upaya saat ini dan dengan mengembangkan kearifan lokal agar ikan endemik terjaga populasinya.
\end{abstract}

Kata Kunci: aspek biologi, Merauke, tenggiri Papua, tingkat pemanfaatan, WPP 718 


\section{PENDAHULUAN}

Arafura merupakan perairan di Timur Indonesia yang memiliki sumberdaya ikan potensial. Laut Arafura mempunyai tingkat kesuburan tinggi karena mengandung konsentrasi klorofil dan unsur hara tinggi dari upwelling serta suhu hangat yang mendukung kelimpahan sumberdaya (Prisantoso dan Badrudin, 2010; Salim dan Kelen, 2018). Perairan ini menjadi daerah penangkapan ikan bagi pelaku usaha dengan berbagai jenis alat tangkap (Mahulette and Samu-samu, 2014). Sumberdaya yang menjadi daya tarik utama adalah udang dan ikan demersal serta ikan pelagis. Kegiatan penangkapan ikan di Arafura dilakukan dengan menggunakan alat tangkap berupa trawl, pukat ikan, jaring dan pancing yang banyak dioperasikan oleh kapal asing. Namun, sejak diberlakukannya Peraturan Menteri Kelautan dan Perikanan Nomor 56/PERMEN-KP/2014 tentang Penghentian Sementara (Moratorium) Perizinan Usaha Perikanan Tangkap di WPPNRI maka nelayan di perairan ini tidak lagi menggunakan trawl. Kapal asing yang mendominasi penangkapan di wilayah ini juga sudah tidak lagi melakukan kegiatan di perairan Arafura. Salah satu wilayah yang masuk ke perairan Arafura adalah Merauke.

Daerah perikanan di wilayah perairan Merauke dimanfaatkan oleh nelayan, baik nelayan kecil kurang dari 10 GT, menengah 10-30 GT, maupun nelayan dengan skala di atas 30 GT. Nelayan 1-10 GT umumnya menggunakan jaring dan pancing sebagai alat penangkapan ikan. Ikan-ikan yang tertangkap dari berbagai jenis ikan pelagis seperti ikan paha-paha (Leptobrama pectoralis), tenggiri Papua (Scomberomorus muliradiatus) maupun ikan demersal seperti ikan bandang (Polydactylus plebeius). Ikan tenggiri termasuk ikan pelagis besar dan ikan perenang cepat. Berdasarkan hasil studi meristik menunjukkan bahwa terdapat 3 (tiga) jenis ikan spesies Scomberomorus yang berada di bagian barat garis Wallace yaitu $S$. guttatus, S. koreanus dan S. lineolatus, sedangkan di bagian timur ditemukan 4 (empat) spesies yaitu $S$. multiradiatus, $S$. semifasciatus, $S$. queenslandicus dan $S$. munroi (Collette and Russo, 1984 dalam Sulaiman and Ovenden, 2010).

Ikan tenggiri ( $S$. multiradiatus) merupakan ikan endemik di perairan Papua khususnya di Merauke. Ikan tenggiri Papua termasuk dalam klasifikasi family Scombridae yang berbeda dengan ikan tenggiri lainnya. Perbedaannya adalah jumlah tulang belakang ikan ini terbanyak yaitu 5556 dibandingkan dengan jenis lainnya seperti S. commerson (42-46) S. niphonius (48-50) S. semifasciatus (44-46) (Collete et al., 1980). Munro dalam Collette (2003) menyatakan bahwa ikan ini terdistribusi di Teluk Papua sekitar Muara Sungai Terbang dan hampir tidak didaratkan di wilayah lain selain di perairan Merauke.

Potensi ikan pelagis besar secara umum di WPP 718 sebesar 818.870 ton dengan jumlah tangkapan yang diperbolehkan 655.096 ton dan tingkat pemanfaatan $\mathrm{E}=0,99$, yang artinya sudah mendekati batas maksimum E $=1$ (KEPMEN KP Nomor 50 Tahun 2017). Oleh karena itu upaya penangkapan ikan pelagis besar termasuk ikan tenggiri Papua sudah hampir mencapai batas over exploited. Pemanfaatan ikan ini hanya dilakukan untuk konsumsi lokal namun produksinya mengalami peningkatan dari tahun 2014 sebanyak $38.122 \mathrm{~kg}$ menjadi $182.171 \mathrm{~kg}$ tahun 2018 (BPS Merauke, 2015; BPS Merauke, 2018). Penangkapan ikan ini dilakukan oleh nelayan dengan jaring insang hanyut pada kedalaman perairan 3-4 meter. Jumlah alat tangkap jaring insang hanyut sejak tahun 2010 sebanyak 17.958 unit meningkat menjadi 19.418 unit tahun 2014 (BPS Merauke, 2015).

Produksi ikan tenggiri Papua yang meningkat menjadi indikasi terjadinya peningkatan upaya penangkapan. Peningkatan upaya penangkapan ikan akan dapat menyebabkan perubahan dari populasi 
ikan serta mengancam kepunahan. Upaya penangkapan yang terus meningkat dapat menyebabkan ikan-ikan kecil, ikan matang gonad dan akan memijah ikut tertangkap. Menurut Noegroho dan Hidayat (2014) menyebutkan bahwa untuk mengatasi penangkapan ikan tenggiri secara intensif diperlukan manajemen dalam upaya penangkapan ikan. Manajemen upaya penangkapan ikan memerlukan kajian ilmiah terutama pada ikan tenggiri. Kajian ilmiah ikan tenggiri jenis $S$. commerson dan $S$. guttatus telah banyak diperoleh informasi ilmiahnya, namun kajian tentang ikan tenggiri Papua ( $S$. multiradiatus) hampir tidak ditemukan. Tulisan ini akan membahas tentang aspek biologi ikan tenggiri dan pemanfaatannya dengan menggunakan jaring insang hanyut. Hasil kajian ini akan menjadi dasar dalam pengelolaan ikan tenggiri Papua di perairan Arafura khususnya perairan Merauke.

\section{METODE PENELITIAN}

\subsection{Pengumpulan Data}

Penelitian dilakukan di perairan Merauke dan sekitarnya selama 2 (dua) tahun yaitu Maret hingga Desember 2017 dan April hingga Desember 2018 dengan metode survei. Kegiatan pengumpulan data dibantu secara bulanan yang dilakukan oleh enumerator dengan mengunjungi nelayan yang mendaratkan hasil tangkapan di Pantai Lampu Satu, Merauke. Pendataan hasil tangkapan dilakukan dengan mengamati serta mencatat jumlah tangkapan di beberapa nelayan yang menggunakan alat tangkap jaring setiap bulan.

Kegiatan pengamatan dan pengukuran sampel dilakukan oleh enumerator setiap bulan ditambah dengan frekuensi kedatangan peneliti ke lapangan. Jumlah sampel ikan tenggiri Papua yang diukur dan diamati adalah sebanyak 4.026 ekor (2017) dan 3.202 ekor (2018) (Gambar 1). Kegiatan pengukuran panjang serta bobot ikan dilakukan dengan menggunakan timbangan digital dengan ketelitian 0,01 gram dan penggaris. Aspek biologi yang diamati adalah panjang ekor (fork length), bobot dan rasio kelamin serta tingkat kematangan gonad. Rasio kelamin dan tingkat kematangan gonad diamati dengan membedah perut ikan. Namun, pengamatan kelamin dan gonad ikan tidak dilakukan oleh tenaga enumerator, sehingga hanya pada saat peneliti ke lokasi penelitian dilakukan pembedahan. Daerah penangkapan ikan tenggiri Papua disajikan pada Gambar 2.

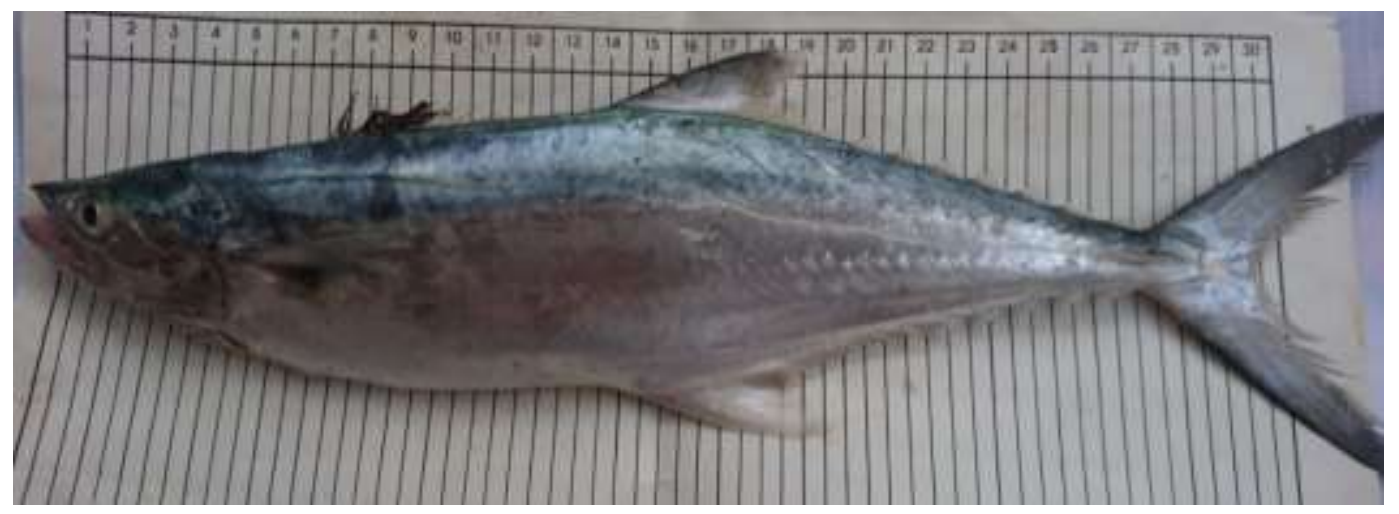

Gambar 1. Ikan tenggiri Papua (S. multiradiatus). 


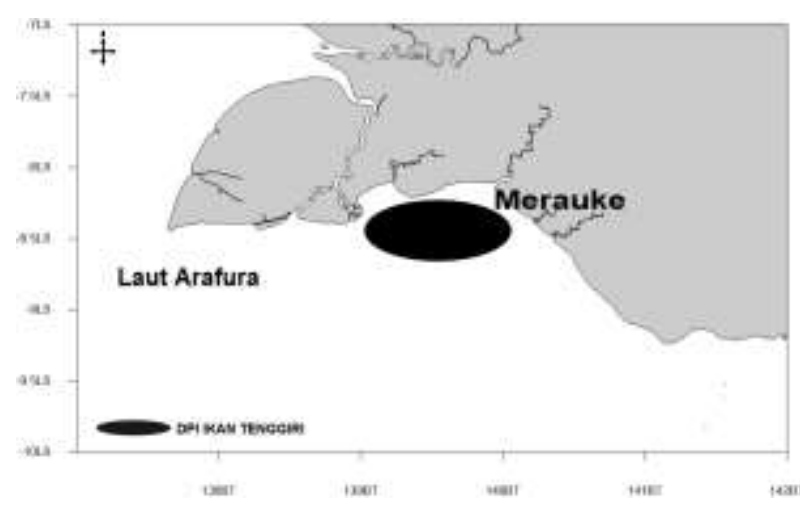

Gambar 2. Daerah penangkapan ikan tenggiri Papua (S. multiradiatus) di perairan Merauke dan sekitarnya.

\subsection{Analisis Data}

Hasil tangkapan nelayan ditabulasi dalam bentuk tabel dan dianalisis untuk memperoleh gambaran jumlah hasil tangkapan dominan dan komposisi hasil tangkapan nelayan dengan alat tangkap jaring. Hubungan panjang berat ikan tenggiri dianalisis untuk mengetahui sifat pertumbuhan ikan tenggiri Papua. Hasil analisis menjadi salah satu faktor yang perlu diketahui dalam kaitan pengelolaan sumber daya perikanan. Persamaan yang digunakan adalah (Balland Rao, 1984),

$\mathrm{W}=\mathrm{a} \mathrm{L}^{\mathrm{b}}$

\section{Keterangan:}

$\mathrm{W}=$ bobot tubuh ikan tengggiri (gram),

$\mathrm{L}=$ fork length $(F L)(\mathrm{cm})$,

$\mathrm{a}=$ konstanta

$\mathrm{b}=$ nilai eksponensial.

Struktur ukuran panjang cagak (FL) ikan yang diperoleh secara bulanan ditabulasi dan dianalisis sebagai ukuran pertama kali tertangkap (length at first capture, $\mathrm{L}_{\mathrm{c}}$ ). Selanjutnya dibentuk grafik hubungan antara distribusi kelas panjang cagak (sumbu $\mathrm{x}$ ) dengan persentase kumulatif jumlah ikan (sumbu y), sehingga terbentuk kurva berbentuk $\mathrm{S}$ (sigmoid). Nilai $\mathrm{L}_{c}$ dinyatakan sebagai titik potong antara kurva 50\% frekuensi kumulatif dengan nilai lebar karapas (Saputra, 2009). Analisis ukuran pertama kali matang gonad tidak dapat ditentukan karena keterbatasan jumlah sampel ikan betina yang dibedah saat penelitian.

Parameter pertumbuhan ( $\mathrm{K}$ dan $\mathrm{CW} \infty$ ) ditentukan dengan metode ELEFAN (Gayanilo et al., 1993). Laju kematian total (Z) diduga dengan metode kurva hasil tangkapan (catch cuve) yang merupakan slope (b) antara Ln N/t dengan umur relatif (Sparre dan Venema, 1999), sesuai dengan rumus sebagai berikut:

$\operatorname{Ln} N / t=a-Z t$

Keterangan:

$\mathrm{N}=$ banyaknya ikan tenggiri pada waktu $\mathrm{t}$

$\mathrm{t}$ = waktu yang diperlukan untuk tumbuh suatu kelas panjang

$\mathrm{a}=$ hasil tangkapan yang dikonversikan terhadap panjang

Tingkat kematangan gonad ikan tenggiri diamati secara visual dengan mengamati morforlogi gonad berdasarkan Grandcourt et al. (2005). Selanjutnya pendugaan umur teoritis pada saat panjang ikan tenggiri Papua sama dengan nol (to) digunakan rumus empiris Pauly (1980) dalam Sparre and Venema (1999) sebagai berikut:

$\log \left(-\mathrm{t}_{\mathrm{o}}\right)=-0,3922-0,2752 \log \left(\mathrm{CW}_{\infty}\right)-$ $1,308 \log (\mathrm{K})$......

Keterangan:

L $\infty=$ Lebar asimptot ikan tenggiri Papua $(\mathrm{cm})$

$\mathrm{K}=$ Koefisien laju pertumbuhan (per tahun)

to $=$ Umur teoritis ikan tenggiri Papua pada saat lebarnya sama dengan nol (tahun)

Kematian alamiah ikan tenggiri Papua dianalisa dengan menggunakan rumus Pauly (1980) yaitu sebagai berikut: 
Ln $M=-0,152-(0,279 \operatorname{Ln} \mathrm{L} \infty)+(0,6543$ $\mathrm{Ln} \mathrm{K})+(0,4534 \mathrm{Ln} \mathrm{T}$.

\section{Keterangan:}

$\mathrm{M}=$ laju kematian alamiah

$\mathrm{L}=$ fork length maksimun (mm)

$\mathrm{K}=$ laju pertumbuhan ( $\mathrm{mm} /$ tahun)

$\mathrm{T}=\operatorname{suhu}\left({ }^{\circ} \mathrm{C}\right)$

Selanjutnya berdasarkan nilai kematian alamiah maka nilai kematian karena penangkapan dapat diperoleh dengan menggunakan laju kematian total $(\mathrm{Z})$ dengan laju kematian alamiah (M) atau $F=Z-M$ dan laju pengusahaan (E) dihitung sebagai $E$ $=\mathrm{F} / \mathrm{Z}$ (Sparre and Venema, 1999).

\section{HASIL DAN PEMBAHASAN}

\subsection{Hasil}

\subsubsection{Komposisi Hasil Tangkapan}

Komposisi hasil tangkapan ikan dengan menggunakan jaring tahun 2017 didominasi oleh ikan kakap putih ( $L$. calcalifer) sebanyak 35\%, ikan gulama (Pennahia) sp 29\% dan ikan tenggiri Papua hanya sebesar $6 \%$ dari total hasil tangkapan (Gambar 3). Sedangkan pada tahun 2018 perbandingan ikan senangin atau bandang $(P$. plebeius) dan ikan tenggiri Papua ( $S$. multiradiatus) sebesar 9:1. Artinya dominan ikan yang tertangkap dengan jaring insang hanyut adalah ikan bandang (Gambar 4).

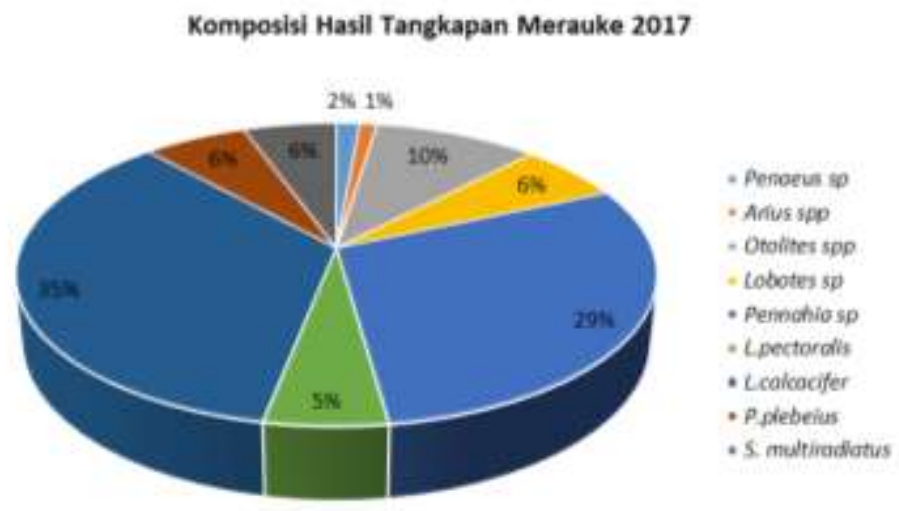

Gambar 3. Komposisi hasil tangkapan jaring di perairan Merauke dan sekitarnya, 2017.

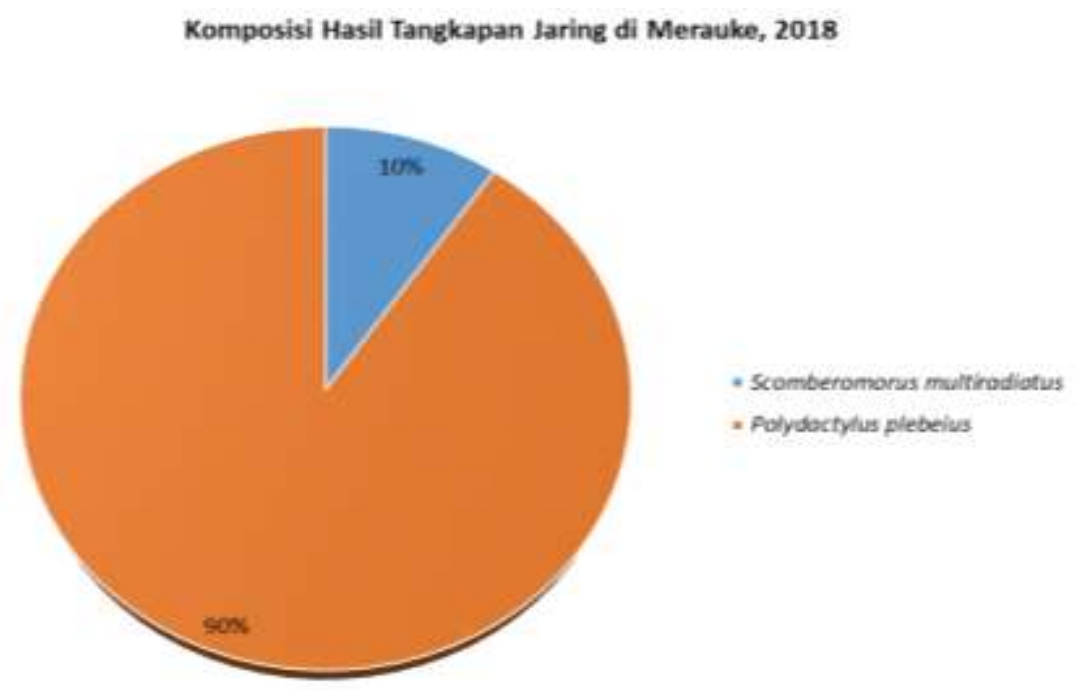

Gambar 4. Komposisi hasil tangkapan jaring di perairan Merauke dan sekitarnya, 2018. 


\subsubsection{Aspek Biologi Ikan Tenggiri}

a. Hubungan panjang ekor (FL) dan bobot tubuh serta nisbah kelamin

Hubungan panjang ekor (FL) ikan tenggiri dengan bobot tubuh di perairan ini menunjukkan hubungan pertumbuhan allometrik positif pada jenis jantan ataupun betina, yang artinya pertambahan bobot tubuh ikan lebih cepat daripada pertambahan panjang tubuhnya (FL) (Tabel 1).

Tabel 1. Hubungan lebar karapas ikan tenggiri Papua di Merauke.

\begin{tabular}{lcccc}
\hline Jenis & $\mathrm{a}$ & $\mathrm{B}$ & $\mathrm{R}^{2}$ & $\begin{array}{c}\text { Sifat } \\
\text { Pertumbuhan }\end{array}$ \\
\hline $\begin{array}{l}2017 \\
\text { Gabungan }\end{array}$ & 0.0045 & 3.248 & 0.9912 & $\begin{array}{c}\text { Allometrik } \\
\text { Positif }\end{array}$ \\
$\begin{array}{l}2018 \\
\text { Gabungan }\end{array}$ & 0.0055 & 3.1826 & 0.9402 & $\begin{array}{c}\text { Allometrik } \\
\text { Positif }\end{array}$ \\
\hline
\end{tabular}

Selama penelitian dilakukan, ikan dibedah dan diamati jenis kelaminnya serta dilakukan uji Chi-kuadrat. Hasil pengujian menunjukkan nisbah kelamin ikan tenggiri Papua tidak seimbang antara ikan tenggiri betina dengan jantan yang disajikan pada Tabel 2. Tingkat kematangan gonad ikan betina dan jantan didominasi belum matang gonad, namun keterbatasan jumlah sampel, sehingga tidak dapat diprediksi puncak musim pemijahan ikan (Tabel 3).

Tabel 2. Nisbah Kelamin ikan tenggiri Papua ( $S$. multiradiatus).

\begin{tabular}{ccccc}
\hline Tahun & \multicolumn{2}{c}{ Jenis Kelamin } & \multicolumn{2}{c}{ Nisbah Kelamin } \\
& $\begin{array}{c}\text { Betina } \\
\text { (Ekor) }\end{array}$ & $\begin{array}{c}\text { Jantan } \\
\text { (Ekor) }\end{array}$ & Betina & Jantan \\
\hline 2017 & 10 & 43 & 1 & 4.3 \\
2018 & 39 & 161 & 1 & 4.1 \\
\hline
\end{tabular}

Tabel 3. TKG ikan tenggiri Papua (S. multiradiatus).

\begin{tabular}{lcccc}
\hline \multirow{1}{*}{ Bulan } & \multicolumn{2}{c}{ Betina } & \multicolumn{2}{c}{ Jantan } \\
& Immature & Mature & Immature & Mature \\
\hline 2017 & & & & \\
September & 9 & 1 & 42 & 1 \\
2018 & & & & \\
Juli & 6 & 2 & 35 & 1 \\
September & 18 & 13 & 104 & 9 \\
Nopember & & & 12 & \\
\hline
\end{tabular}

\section{b. Struktur Ukuran}

Sebaran ukuran ikan tenggiri di Merauke yang ditemukan selama masa penelitian adalah $21-49 \mathrm{~cm}$ (2017) dan 25 $49 \mathrm{~cm}$ (2018). Struktur ukuran panjang ekor (FL) tiap bulan disajikan pada Tabel 4. Ikan yang ditemukan dominan pada ukuran 33 cmFL baik pada tahun 2017 dan 2018 dengan $97,9 \%$ - $99 \%$ berada dibawah ukuran 40 cmFL (Gambar 5).

Tabel 4. Struktur ukuran tenggiri Papua (S. multiradiatus).

\begin{tabular}{ccccc}
\hline Tahun & \multicolumn{2}{c}{2017} & \multicolumn{2}{c}{2018} \\
Bulan & Kisaran $(\mathrm{cm})$ & Dominan $(\mathrm{cm})$ & Kisaran $(\mathrm{cm})$ & Dominan $(\mathrm{cm})$ \\
\hline Maret & $25-49$ & 33 & & \\
Apr & $25-49$ & 33 & $25-37$ & 33 \\
Mei & $21-49$ & 33 & $25-37$ & 31 \\
Jun & $25-43$ & 33 & $25-39$ & 33 \\
Juli & $23-43$ & 33 & $25-49$ & 33 \\
Agust & $25-49$ & 33 & $25-37$ & 33 \\
Sept & $23-49$ & 33 & $25-39$ & 33 \\
Okt & $25-37$ & 33 & $25-49$ & 33 \\
Nop & $25-39$ & 33 & $25-30$ & 27 \\
Des & $25-49$ & 33 & $25-43$ & 33 \\
\hline
\end{tabular}



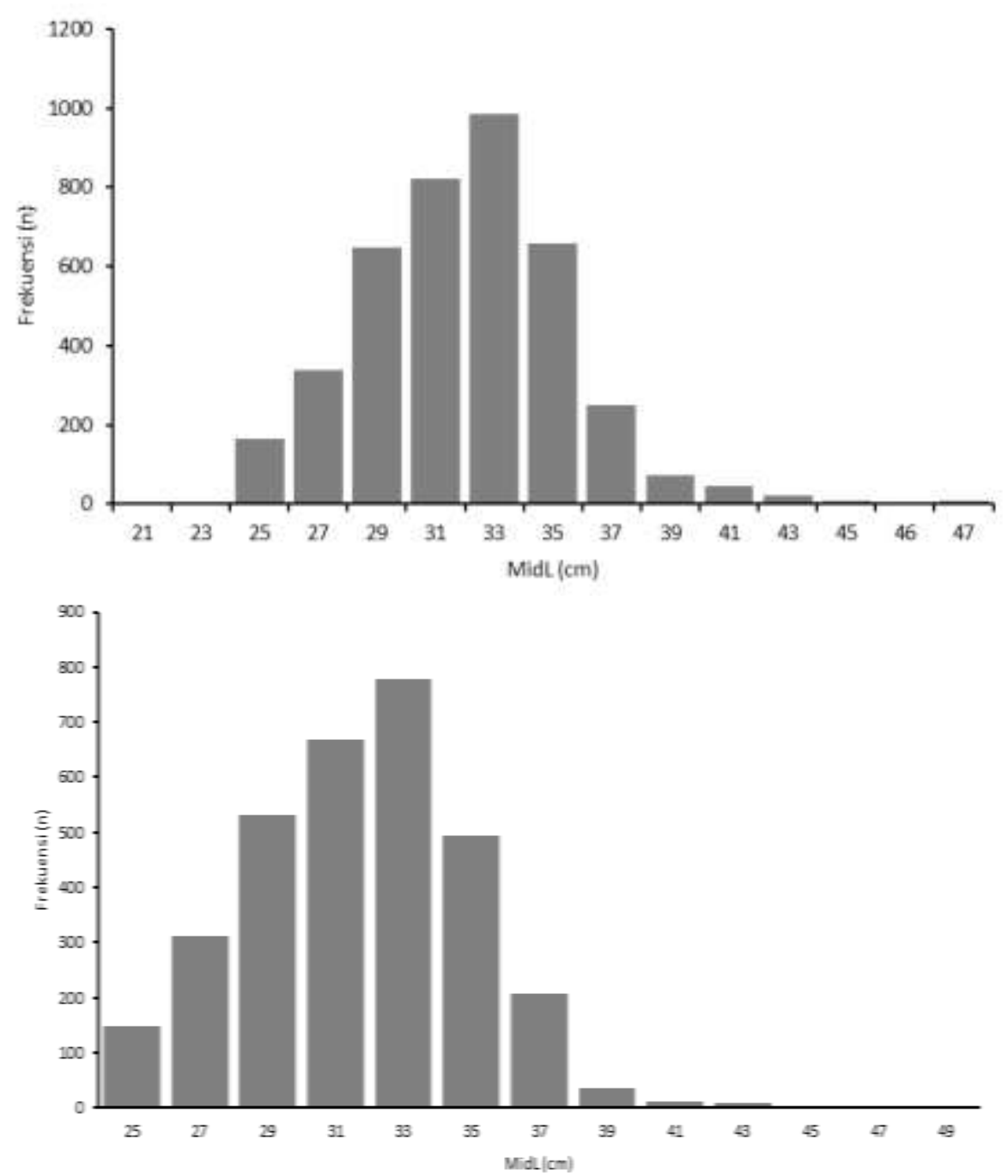

Gambar 5. Struktur ukuran ikan tenggiri Papua (S.multiradiatus) di perairan Kabupaten Merauke dan sekitarnya.

\subsubsection{Parameter Pertumbuhan, Ukuran Pertama Kali Tertangkap $\left(L_{c}\right)$ dan Tingkat Pemanfaatan}

Nilai laju pertumbuhan (K) dan panjang maksimum (Loo) pertumbuhan ikan tenggiri Papua di perairan Merauke dan sekitarnya pada tahun 2017 (Tabel 5) mengikuti persamaan $\mathrm{Lt}=32.08\left[1-\mathrm{e}^{-0.62(\mathrm{t}-}\right.$ $\left.{ }^{0.21908)}\right]$ dan tahun $2018 \mathrm{Lt}=30.50\left[1-\mathrm{e}^{-0,64(\mathrm{t}-}\right.$ ${ }^{0.21244)}$ ]. Tingkat pemanfaatan (E) tenggiri sebesar 0,68 per tahun (2017) dan 0,70 per tahun (2018) yang menggambarkan pemanfaatan ikan tenggiri Papua di perairan ini sudah mengalami over exploited.
Tabel 5. Nilai parameter populasi ikan tenggiri Papua di perairan Merauke dan sekitarnya, 2017 - 2018.

\begin{tabular}{lcrr}
\hline \multirow{2}{*}{ Parameter } & \multirow{2}{*}{ Satuan } & \multicolumn{2}{c}{ Nilai } \\
\cline { 3 - 4 } & & 2017 & 2018 \\
\hline $\begin{array}{l}\text { Ukuran } \\
\text { pertama kali } \\
\text { tertangkap }\left(\mathrm{L}_{\mathrm{c}}\right)\end{array}$ & $\mathrm{cm}$ & 32.08 & 30.50 \\
$\begin{array}{l}\text { Panjang cagak } \\
\text { maksimum }\end{array}$ & $\mathrm{cm}$ & 56.75 & 56.30 \\
$\begin{array}{l}\text { (FL) } \\
\text { Laju } \\
\text { pertumbuhan } \\
(\mathrm{K})\end{array}$ & Tahun & 0.62 & 0.64 \\
\hline
\end{tabular}




\begin{tabular}{|c|c|c|c|}
\hline \multirow{2}{*}{ Parameter } & \multirow{2}{*}{ Satuan } & \multicolumn{2}{|c|}{ Nilai } \\
\hline & & 2017 & 2018 \\
\hline $\begin{array}{l}\text { Umur pada } \\
\text { saat panjang } \\
\text { sama dengan } \\
\text { nol }\left(\mathrm{t}_{0}\right)\end{array}$ & Tahun & -0.21908 & -0.21244 \\
\hline $\begin{array}{l}\text { Kematian total } \\
\text { (Z) }\end{array}$ & Tahun & 3.44 & 3.76 \\
\hline $\begin{array}{l}\text { Kematian } \\
\text { Alamiah (M) }\end{array}$ & Tahun & 1.11 & 1.14 \\
\hline $\begin{array}{l}\text { Kematian } \\
\text { penangkapan } \\
\text { (F) }\end{array}$ & Tahun & 2.33 & 2.62 \\
\hline $\begin{array}{l}\text { Tingkat } \\
\text { pemanfaatan } \\
\text { (E) }\end{array}$ & & 0.68 & 0.70 \\
\hline
\end{tabular}

Berdasarkan hasil analisis struktur ukuran panjang cagak ikan, diperoleh ukuran pertama kali tertangkap (Lc) ikan tenggiri Papua di perairan Merauke dan sekitarnya adalah 32,08 cm (2017) dan 30,50 cm (2018). Artinya ikan tenggiri Papua yang tertangkap mengalami penurunan ukuran panjang cagak (FL) (Gambar 6).

\subsection{Pembahasan}

Jaring yang digunakan untuk menangkap ikan tenggiri adalah jaring insang hanyut berbahan nilon dengan ukuran tinggi badan jaring 3 meter, ukuran mata jaring 3 inch dan rata-rata nelayan membawa 35 psc. Komposisi hasil tangkapan mulai dari ikan demersal dan ikan pelagis serta sebagian kecil udang. Ikan pelagis tidak mendominasi hasil tangkapan karena jaring ini dioperasikan di perairan yang dangkal. Ikan tenggiri Papua tertangkap hanya sekitar 6$10 \%$ dari total hasil tangkapan, sedangkan dominannya adalah ikan demersal. Jenis ikan demersal antara lain Polydactylus plebeius, Lates calcalifer dan Pennahia sp, serta udang sekitar $2 \%$.

Ukuran ikan tenggiri Papua berkisar antara $21-49 \mathrm{cmFL}$ dan rata-rata mencapai ukuran 33 cmFL sebanyak 95\%, sedangkan ikan yang berukuran diatas $40 \mathrm{cmFL}$ hanya ditemukan sekitar 5\%. Ukuran ikan ini lebih panjang daripada saat ditemukan tahun 2016 yaitu $22-45 \mathrm{cmFL}$ (Kembaren et al., 2019) dan secara umum ini lebih besar daripada yang ditemukan oleh Froese and Pauly (2000) dan Fish Base (2000) dalam Pauly and Palomares (2005) dengan panjang maksimum 33 cmSL. Hal yang mempengaruhi perubahan ukuran adalah ketersediaan makanan di lingkungan, umur, alat tangkap serta kondisi lingkungan itu sendiri (Restianingsih et al., 2016).

Hasil pengukuran panjang bobot tubuh ikan tenggiri menunjukkan pola pertumbuhan yaitu bersifat allometrik positif dimana pertambahan bobot tubuh lebih dominan daripada pertambahan panjang tubuh. Banyak yang mempengaruhi pola pertumbuhan terutama makanan dan kondisi lingkungan. Makanan menjadi faktor penentu keberhasilan hidup individu dan mempengaruhi pertumbuhannya (Prianto et al., 2012). Lebih lanjut ditambahkan oleh Ahmed et al. (2014) bahwa spesies yang sama namun berbeda habitat hidup dapat terjadi, terdapat perbedaan hubungan panjang bobot karena dipengaruhi oleh makanan dan reproduksi serta sifat ikan tersebut.

Berdasarkan pengamatan gonad ikan maka diperoleh hasil nisbah kelamin ikan jantan lebih dominan dibandingkan ikan betina. Hal ini dapat menjadi tanda bahwa telah terjadi ketidakseimbangan populasi. Nisbah kelamin berkaitan dengan pertambahan populasi di lingkungan perairan tersebut (Kembaren dan Ernawati, 2011). Ketidakseimbangan nisbah kelamin memberikan pengaruh pada pertambahan individu di perairan karena nisbah kelamin yang seimbang lebih memberikan kemungkinan terjadinya pembuahan sel telur (Effendi, 1979). Bahkan Persada (2016) menyatakan bahwa jika ikan jantan lebih dominan dibandingkan ikan betina maka dapat menyebabkan penurunan stok populasi. 


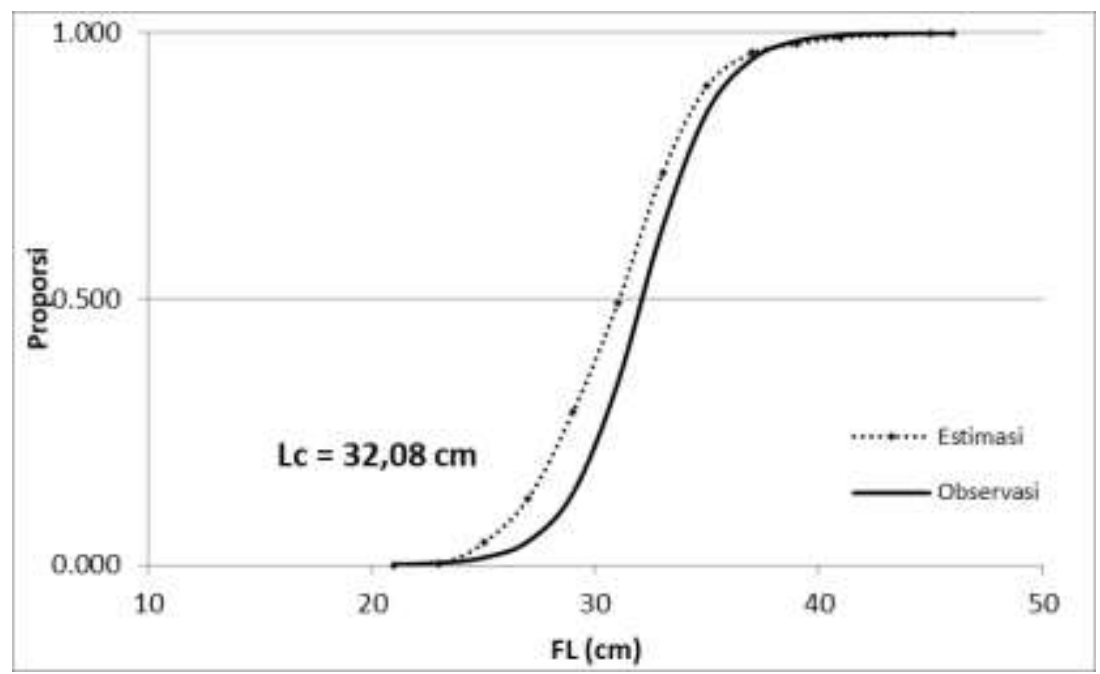

(a)

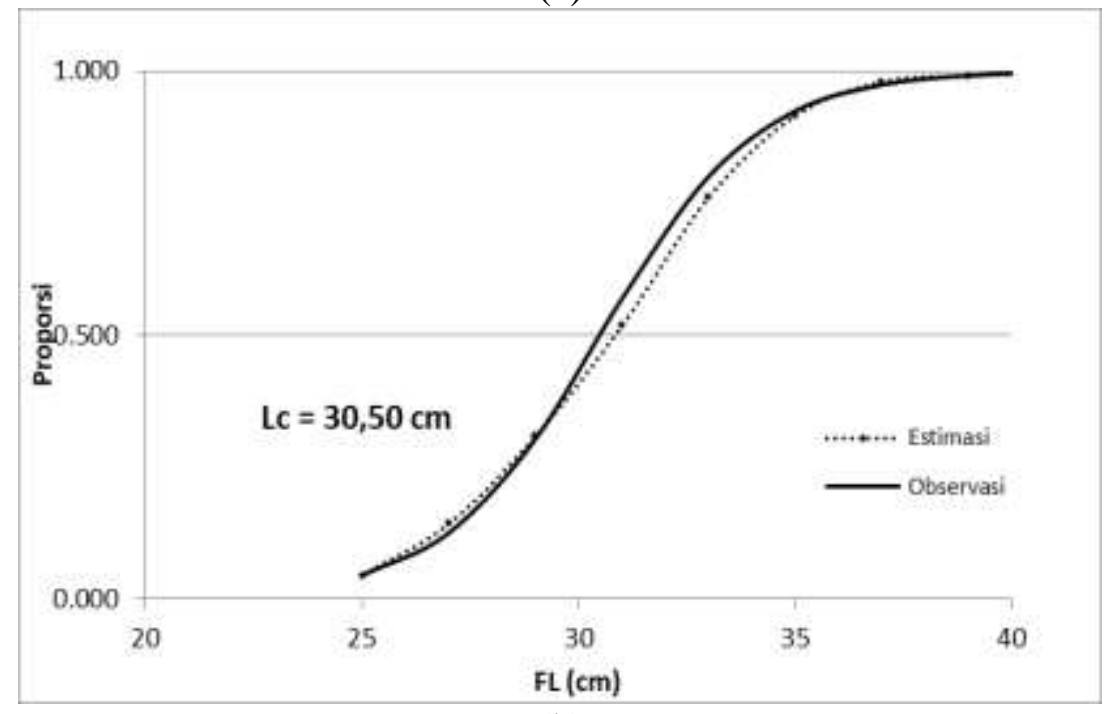

(b)

Gambar 6. Ukuran pertama kali tertangkap (Lc) S. multiradiatus Merauke (a) Tahun 2017, (b) Tahun 2018.

Persentase ikan yang mengalami kematangan gonad (mature) lebih kecil dibandingkan ikan yang belum matang gonad (immature), hal tersebut dapat disebabkan oleh nelayan yang melakukan penangkapan disekitar daerah asuhan yaitu daerah pantai (Noegroho et al., 2018). Ikan tenggiri (Scomberomorus $s p$ ) bersifat stenohalin yaitu menyukai daerah salinitas yang sempit yaitu 33 - 34 ppt dan daerah yang kaya fitoplankton serta klorofil-a seperti daerah pantai (Nontji, 2005; Bukhari et al., 2017). Kematangan gonad individu juga dipengaruhi oleh faktor fisika, kimia dan biologi dari lingkungan perairan (Mardlijah dan Patria, 2012).

Ikan yang pertama kali tertangkap (Lc) pada penelitian ini yaitu pada tahun 2017 dengan ukuran $32.08 \mathrm{cmFL}$ (2017) dan 30.50 cmFL (2018), sedangkan pada tahun 2016 adalah 30,8 cmFL (Kembaren et al., 2019) yang menunjukkan adanya perbedaan disetiap tahunnya. Banyak hal yang mendasari perbedaan ukuran diantaranya sampel yang diukur, lokasi pengambilan sampel dan lingkungan hidup ikan. Menurut Ahmed et al. (2016) perbedaan dapat terjadi 
karena analisa ukuran frekuensi panjang sampel dan perbedaan pertumbuhan.

Ikan tenggiri mempunyai nilai koefisen pertumbuhan (K) 0,62-0,64 menunjukkan bahwa pertumbuhan ikan tenggiri tergolong lambat. Nilai koefisen pertumbuhan (K) menunjukkan tingkat waktu yang diperlukan individu untuk mencapai panjang asimtotiknya (Sparre and Venema, 1999). Jika nilai koefisen pertumbuhan (K) semakin rendah maka individu tersebut semakin lama membutuhkan waktu untuk mencapai panjang asimtotiknya dan sebaliknya. Semakin lambat mencapai panjang maka membutuhkan waktu lebih lama untuk mencapai ukuran dewasa dan menambah jumlah populasi. Pola pertumbuhan berkaitan erat dengan makanan yang tersedia di lingkungan (Restianingsih dan Amri, 2018).

Nilai laju pertumbuhan (K) dan nilai laju kematian ikan secara alamiah (M) merupakan hal penting dalam pengelolaan perikanan tenggiri (Noegroho et al., 2018). Ikan tenggiri sendiri termasuk ikan yang bermigrasi dengan cepat sehingga untuk laju mortalitas alami (M) dapat dikalikan dengan 0.8 (Pauly, 1980). Jika nilai laju mortalitas tersebut dikalikan dengan 0.8 diperoleh nilai $\mathrm{M}=0.88$ (2017) dan $\mathrm{M}=0.912$ (2018) dan ini tergolong rendah karena menurut Beverton and Holt (1959) dalam Sparre and Venema (1999) bahwa M tinggi antara 1.5 2.5. Nilai laju kematian total (Z) menjadi 3.21 (2017) dan 3.532 (2018) setelah ditambahkan kematian alamiah (M) dengan kematian karena penangkapan (F). Dengan demikian dapat diketahui bahwa ikan tenggiri Papua lebih dominan mati akibat penangkapan dibandingkan dengan kematian alamiah. Kematian akibat penangkapan yang meningkat berhubungan erat dengan peningkatan upaya penangkapan (Hidayat et al., 2017). Pengendalian upaya penangkapan harus dilakukan untuk menjaga keseimbangan populasi ikan tenggiri Papua.

Nilai tingkat pemanfaatan ikan tenggiri Papua di perairan Merauke mengalami peningkatan dari $\mathrm{E}=0.68$ (2017) menjadi $\mathrm{E}=0.70$ (2018) yang menunjukkan bahwa sudah mengalami kelebihan tangkap (over fishing). Status over fsihing tersebut berdasarkan tingkat pemanfaatan $\mathrm{E}=0,5$ (Pauly et al., 1984). Tingkat pemanfaatan ikan menjadi sekitar $140 \%$ sehingga diperlukan upaya pengurangan pemanfaatan sekitar 40\%. Hal ini sejalan dengan pernyataan Afandy (2016) bahwa efek moratorium di Arafura, udang masih berstatus (fully exploited) dan ikan pelagis kecil (moderate) namun ikan lain baik demersal maupun pelagis besar berstatus over exploited. Pengurangan upaya pemanfaatan dapat dilakukan dengan melakukan pengendalian pemanfaatan sumberdaya. Pengendalian pemanfaatan sumberdaya yang dapat dilakukan dengan pengawasan terhadap ukuran mata jaring dan daerah penangkapan yang tidak dilakukan di daerah asuhan (nursery ground). Sementara menurut Motlagh and Shojaei (2009); Noegroho et al. (2018) hal lain yang dapat dilakukan adalah dengan menetapkan aturan ukuran mata jaring yang digunakan, mengatur kuota penangkapan ikan tenggiri, serta mengatur ukuran minimum ikan yang tertangkap.

Tenggiri termasuk golongan ikan dalam kategori near threatened (NT) yang menunjukkan bahwa ikan ini terancam punah dalam waktu dekat (Collete et al., 2011). Oleh karena itu diperlukan usaha dalam menjaga kelestarian stok ikan tenggiri Papua agar tidak mengalami kepunahan. Menjaga populasi ikan tenggiri Papua memerlukan kebijakan dibidang konservasi, penanaman pemahaman nelayan tentang lingkungan, serta penyuluhan tentang kearifan lokal yang berlaku di masyarakat yang dapat mendukung produktivitas laut dan perbaikan kondisi sumber daya ikan (Hakim et al., 2014). Pemerintah Daerah melalui lembaga yang dekat dengan masyarakat nelayan atau organisasi yang menangani tentang lingkungan dapat memberikan penyuluhan dan himbauan tentang kegiatan penangkapan. 
Mahuletten and Samu-samu (2014) pengelolaan sumberdaya perikanan memerlukan otoritas pengelolaan atau kelembagaan otoritas pengelolaan yang kuat. Kondisi masyarakat Papua yang masih patuh dan menjaga masukkan dari kepala Suku dapat menjadi bentuk kearifan lokal yang dapat dipatuhi nelayan lokal maupun nelayan pendatang. Kelestarian populasi ikan tenggiri Papua yang endemik multak dilakukan untuk mempertahankan populasinya.

\section{KESIMPULAN}

Ikan tenggiri Papua (S. multiradiatus) tertangkap sekitar 6-10\% dari total hasil tangkapan jaring insang hanyut di perairan Merauke dan sekitarnya. Struktur ukuran ikan yang tertangkap dominan dibawah 40 cmFL (fork length). Sifat pertumbuhan ikan adalah allometrik positif dengan rasio kelamin ikan jantan lebih dominan daripada ikan betina. Penurunan ukuran ikan pertama kali tertangkap (Lc) menjadi salah satu indikasi bahwa ukuran panjang cagak ikan yang tertangkap semakin kecil. Penangkapan ikan ini dilakukan oleh nelayan dengan menggunakan jaring namun nilai kematian akibat penangkapan (F) lebih tinggi dibandingkan dengan kematian ikan secara alamiah (M). Upaya pemanfaatan ikan tenggiri ini harus dilakukan pengendalian karena tingkat pemanfaatan sudah mencapai $140 \%$ sehingga diperlukan upaya pengurangan penangkapan sebanyak $40 \%$. Hal yang dapat dilakukan oleh Pemerintah Daerah adalah melakukan kerjasama dengan kelompok masyarakat pesisir untuk mengembangkan kearifan lokal agar masyarakat nelayan ikut menjaga keberadaan populasi ikan endemik Papua ini.

\section{UCAPAN TERIMA KASIH}

Tulisan ini merupakan kontribusi dari kegiatan Penelitian Karakteristik Biologi Perikanan, Habitat Sumberdaya, dan Potensi Produksi Sumberdaya Ikan di WPP
718 Laut Arafura Tahun Anggaran 2017 dan 2018 pada Balai Riset Perikanan Laut, Cibinong Bogor. Penulis mengucapkan terima kasih kepada Drs. Suprapto dan Prof Ali Suman sebagai Penanggungjawab kegiatan penelitian WPP 718 Tahun 2017 dan 2018 serta tenaga enumerator untuk sumberdaya ikan tenggiri di Merauke yaitu Ibu Julia Pramudita. Penulis pertama merupakan kontributor utama dari tulisan ini, sedangkan penulis kedua dan ketiga adalah kontributor anggota.

\section{DAFTAR PUSTAKA}

Afandy, Z. 2016. Efek Moratorium Izin Kapal Perikanan Terhadap Stok Sumberdaya Ikan di Laut Arafura dengan Permodelan Sistem Dinamik. https://www.scribd.com/document/31 7108145/Zulfikar-Afandy-Efek Moratorium-Izin-Kapal-PerikananDengan-Pemodelan-Sistem-DinamikSebagai-Decision-Support-System\#. Diunduh pada 22 Juni 2019 pukul 06.14 Wib.

Ahmed, Q., F. Yousuf., K. Nazim., and M.U. Khan. 2014. Length-weight relationships in three marketable sized mackerel fish species collected from Karachi Fish Harbor, Pakistan. FUUAST J. BIOL, 4(1): 107-111.

Ahmed, Q., S. Bilgin., and L. Bat. 2016. Length based growth estimation of most commercially important Scombridae from offshore Water of Pakistan Coast in the Arabian Sea. Turkish J. of Fisheries and Aquatic Sciences, 16: 15-167. http://doi.org/10.4194/1303-2712v16_1_16

Ball, D.V., and K.V. Rao. 1984. "Marine Fisheries." New Delhi : Tata Mc. Graw-Hill Publishing Company Limited., 5-24 pp.

Badan Pusat Statistik. 2015. Merauke dalam Angka 2015. BPS Kabupaten Merauke. Hlm.: 374. 
Badan Pusat Statistik [BPS]. 2018. Merauke dalam Angka 2018. BPS Kabupaten Merauke. Hlm.: 374.

Bukhari, W. Adi dan Kurniawan. 2017. Pendugaan Daerah Penangkapan Ikan Tenggiri Berdasarkan Distribusi Suhu Permukaan Laut dan Klorofil-a di Perairan Bangka. J. Perikanan Tangkap, 1(3): 1-22.

https://ejournal2.undip.ac.id/index.ph p/juperta/article/view/1871

Collette, B.B., Joseph and J.1. Russo. (1980). Scomberomorus munroi, a new species Of Spanish Mackerel form Australia and New Guinea. Abstrak in Australia J. of Marine Freshwater Research, 31(2): 241-250.

Collette, B.B. 2003. Family Scombridae Rafinesque 1815 - mackerels, tunas, and bonitos. California Academy Science. Annotated Checklists of Fishes, 19: 1-28.

Collette, B., S.K. Chang, A.Di Natale, W. Fox., M.J. Jorda, N. Miyabe, and R. Nelson. 2011. Scomberomorus commerson. The IUCN Red List of Threatened Species 2011: e.T170316A6745396.

Effendie, H.M.I. 1979. Metode Biologi Perikanan (p.112). Bogor: Yayasan Dewi Sri.

Grandcourt, E., T.Z. Abdessalaam., F. Francis., A. T. Shamsi., S. Al Ali., K. Al Ali., S. Hartmann., and A. Al Suwaidi. 2005. Assessment of the fishery of Kingfish (Kanaad. Khabat), Scomberomorus commerson, in the water off Abu Dhabi Emirate. Marine Environmental Research Centre, 34 p.

Hakim, L.L., Z. Anna., dan J. Junianto. 2014. Analisis bioekonomi sumberdaya Ikan Tenggiri (Scomberomorus commerson) di Perairan Kabupaten Indramayu Jawa Barat. J. Kebijakan Sosial Ekonomi Perikanan dan Kelautan, 4(2): 117-127. http://doi.org/10.15578/jksekp.v4i2.5 99
Hidayat, T., T. Noegroho., dan K. Wagiyo. 2017. Struktur ukuran dan beberapa parameter populasi Ikan Cakalang (Katsuwonus pelamis Linnaeus, 1758) di Samudera Pasifik Utara Papua. Bawal, 9(2): 113-121. http://doi.org/10.15578/bawal.9.2.201 7.113-121

Kembaren, D.D. dan T. Ernawati. 2011. Beberapa Aspek Biologi Ikan Kuniran (Upeneus sulphureus) di Perairan Tegal dan Sekitarnya. Bawal, 3(4): 261-267. http://doi.org/10.15578/bawal.3.4.201 1.261-267

Kembaren, D.D., A. Surahman, and T. Noegroho. 2019. Preliminary study on biological aspects of Papua Seerfish (Scomberomorus multiradiatus MUNRO, 1964) in Merauke Watres, Papua, Indonesia. Indonesia Fisheries Research Journal. 25(1): 27-35. http://doi.org/10.15578/ifrj.25.1.2019. 27-35

Mardlijah, S., dan M.P. Patria. 2012. Biologi Reproduksi Ikan Madidihang (Thunnus albacares Bonnatere 1788) di Teluk Tomini. Bawal, 4(1): 27-34. http://doi.org/10.15578/bawal.4.1.201 2.27-34

Mahulette, R.T., dan A.S. Samu. 2014. Penguatan kelembagaan untuk mendukung pengelolaan sumberdaya perikanan Laut Arafura. $J$. Kebijakanan Perikanan Indonesia, 6(2): 87-96.

http://doi.org/10.15578/jkpi.6.2.2014. 87-96

Motlagh, S.A.T., and M.G. Shojaei. 2009. Population dynamics of narrow barred Spanish Mackerel (Scomberomorus commerson) in the Persian Gulf, Bushehr Province, Iran. Indian Journal Fish, 56(1): 7 -11

Mulyana, R., J. Haluan., M.S. Baskoro dan S.H. Wisudo. 2012. Keberlanjutan 
Perikanan Skala Besar di Laut Arafura. Buletin PSP, 20(1): 35-43.

Noegroho, T., dan T. Hidayat. 2014. Dinamika populasi Ikan Tenggiri (Scomberomorus commerson) di Perairan Teluk Kwandang, Laut Sulawesi. J. Penelitian Perikanan Indonesia, 20(4): 251-258. http://doi.org/10.15578/jppi.20.4.201 4.251-258

Noegroho, T., dan T. Hidayat., U. Chodriyah., dan M.P. Patria. 2018. Biologi Reproduksi Ikan Tenggiri (Scomberomorus commerson Lacepede,1800) di Perairan Teluk Kwandang, Laut Sulawesi. Bawal. 10(1): 69-84. http://doi.org/10.15578/bawal.10.1.20 18.69-84

Noegroho, T., M. Boer, Sulistiono, and L. Adrianto. 2018. Size structure and population dynamic of Indo-Pacific King Mackerel (Scomberomorus guttatus) in Kepulauan Riau Water Indonesia. AACL Bioflux, 11(4): 1081-1088.

http://www.bioflux.com.ro/docs/2018 .1081-1088.pdf

Nontji, A. (2005). Laut Nusantara. Djambatan. 372 p.

Pauly, D. and M.L. Palomares. 2005. Fishing Down Marine Food Web: It is Far More Pervasive Than We Thought. Bulletin of Marine Science, 76(2): 197-11.

Persada, L.G., E. Utami. dan D. Rosalina. 2016. Aspek Reproduksi Ikan Kurisi (Nemipterus furcosus) yang Didaratkan di Pelabuhan Perikanan Nusantara Sungailiat (Studi Kasus: Hasil Tangkapan Bulan Maret sampai Mei 2015). Akuatik, 10(2): 46-54. http://journal.ubb.ac.id/index.php/aku atik/article/view/342

Prianto, E., N.K. Suryati., dan M.M. Kamal. 2012. Keberagaman Jenis dan Kebiasaan Makan Ikan di Muara Sungai Musi. Bawal, 4(1): 35-43. http://dx.doi.org/10.15578/bawal.4.1. 2012.35-43

Prisantoso, B.I., dan Badrudin. 2010. Kebijakan Pengelolaan Sumberdaya Ikan Kakap Merah (Lutjanus spp.) di Laut Arafura. J. Kebijakan Perikanan Indonesia, 2(1): 71-78. http://doi.org/10.15578/jkpi.2.1.2010. 71-78.

Restianingsih, Y.H., T. Noegroho, dan K. Wagiyo. 2016. Beberapa Aspek Biologi Ikan Tenggiri Papan (Scomberomorus guttatus) di Perairan Cilacap dan Sekitarnya. Bawal, 8 (3): 191-198.

http://doi.org/10.15578/bawal.8.3.201 6.191-198

Restianingsih, Y.H., dan K. Amri. 2018. Aspek Biologi dan Kebiasaan Makanan Ikan Cakalang (Katsowonus pelamis) di Flores dan Sekitarnya. Bawal, 10(3): 187- 196. http://dx.doi.org/10.15578/bawal.10.3 .2018.187-196

Salim, G., and P.B. Kelen. 2018. El Von Bertalanffy and Mortality from Fish Kurau (Polynemus taenitatus) of the Catch Fisherman in Waters Bunyu. Insist, 3(2): 165-169. http://doi.org/10.23960/ins.v3i2.165

Saputra, S., Wijaya, Prijadi, Sulistyawati, G. Ari. 2009. Beberapa aspek biologi Ikan Kuniran (Upeneus spp.) di Perairan Demak. J. Saintek Perikanan, 5(1): 1-6.

Sparre, $\mathrm{P}$ and S. Venema. 1999. Introduction tp Tropical Fish Stock Assesment. (Introduksi Pengkajian Stok Ikan Tropis, alih bahasa : Pusat Penelitian dan Pengembangan Perikanan). Buku 1 : Manual. Badan Penelitian dan Pengembangan Perikanan. Jakarta. $438 \mathrm{p}$.

Sulaiman, Z.H., and J.R. Ovenden. 2010. Population genetic Evidence for The East-West Divison of The Narrow Barred Spanish Mackerel (Scomberomorus commerson, 
Aspek Biologi dan Pemanfaatan Ikan ...

Perciformes: Teleostei) along Received :03 July 2019

Wallace's Line. Biodivers Conserv, Reviewed : 18 September 2019

19: 563-574.

Accepted : 25 November 2019

https://doi.org/10.1007/s10531-009-

9699-y 